\title{
PENGARUH STRES KERJA DAN DISIPLIN KERJA TERHADAP KINERJA KARYAWAN PADA PT. MULTRITRAN ABADI SRENGSENG JAKARTA BARAT PERIODE 2018
}

\author{
Veta Lidya Delimah Pasaribu', Bambang Purnomo Yanuarso \\ Dosen Fakultas Ekonomi Universitas Pamulang \\ veta01889@unpam.ac.id ${ }^{1}$,dosen02142@unpam.ac.id ${ }^{2}$
}

\begin{abstract}
ABSTRAK
Kinerja adalah proses menyeluruh untuk mengamati kinerja seorang Pegawai dalam hubungannya dengan persyaratan jabatan selama jangka waktu tertentu (yakni, menjelaskan, menetapkan tujuan, memberikan bimbingan langsung tentang bagaimana melakukan pekerjaan, menyimpan dan mengakses informasi tentang kinerja) dan kemudian membuat penilaian tentang kinerja itu. Metode yang digunakan dalam penelitian ini kuantitatif. Data diambil dari hasil kuesioner. Analisis data dilakukan dengan mengunakan 4 (empat) tahapan yaitu pengumpulan data, validitas item, penyajian data dan penarikan kesimpulan. Berdasarkan hasil penelitian menunjukkan bahwa, Terdapat pengaruh positif dan signifikan secara secara simultan antara Stres kerja(X1), Disiplin (X2), Terhadap Kinerja Karyawan (Y) dan yang paling dominan adalah faktor motivasi belajar dengan presentase sebesar 4,28.
\end{abstract}

Kata-kata Kunci: Stres Kerja, Disiplin , Dan Kinerja Karyawan

\begin{abstract}
Performance is the overall process of observing an employee's performance in relation to job requirements over a period of time (i.e. explaining, setting goals, providing direct guidance on how to do work, storing and accessing performance information) and then making judgments about that performance.The method used in this research is quantitative. Data taken from the questionnaire. Data analysis was performed using 4 (four) stages, namely data collection, item validity, data presentation and drawing conclusions. Based on the research results show that, there is a positive and significant effect simultaneously between job stress (X1), Discipline (X2), on Employee Performance $(Y)$ and the most dominant factor is learning motivation with a percentage of 4.28 .
\end{abstract}

Keywords: Job Stress, Discipline, and Employee Performance. 


\section{PENDAHULUAN}

Dalam menghadapi persaingan di era globalisasi perusahaan dituntut untuk bekerja lebih efektif dan efisien. Persaingan yang semakin ketat menyebabkan perusahaan dituntut untuk mampu meningkatkan daya saing dalam rangka menjaga kelangsungan hidup perusahaan. Perusahaan merupakan salah satu organisasi yang menghimpun orang-orang yang biasa disebut dengan Pegawai atau pegawai untuk menjalankan kegiatan rumah tangga produksi perusahaan. Hampir di semua perusahaan mempunyai tujuan yaitu memaksimalkan keuntungan dan nilai bagi perusahaan, dan juga untuk meningkatkan kesejahteraan pemilik dan pegawai.

Pegawai atau pegawai merupakan unsur penting dalam menentukan maju mundurnya suatu perusahaan. Untuk mencapai tujuan perusahaan diperlukan Pegawai yang sesuai dengan persyaratan dalam perusahaan, dan juga harus mampu menjalankan tugas-tugas yang telah ditentukan oleh perusahaan. Setiap perusahaan akan selalu berusaha untuk meningkatkan kinerja Pegawainya dengan harapan apa yang menjadi tujuan perusahaan akan tercapai.

Kemampuan Pegawai tercermin dari kinerja yang baik adalah kinerja yang optimal. Kinerja Pegawai tersebut merupakan salah satu modal bagi perusahaan untuk mencapai tujuannya sehingga kinerja Pegawai hal yang patut diperhatikan oleh pemimpin

perusahaan. Kinerja pada umumnya dapat diartikan sebagai kesuksesan seseorang dalam melaksanakan suatu pekerjaan. Kinerja Pegawai merupakan hasil kerja yang dicapai seseorang dalam melaksanakan tugas-tugas yang dibebankan kepadanya untuk mencapai target kerja, Pegawai dapat bekerja dengan baik bila memiliki kinerja yang tinggi sehingga dapat menghasilkan kerja yang baik. Kinerja merupakan salah satu faktor penting penentu keberhasilan perusahaan dalam mencapai tujuannya, Untuk itu kinerja dari para Pegawai harus mendapat perhatian dari para pimpinan perusahaan, sebab menurunnya kinerja Pegawai dapat mempengaruhi kinerja perusahaan secara keseluruhan.

Menurut Wilson Bangun (2012:4), salah satu sumber daya organisasi yang memiliki peran penting dalam mencapai tujuannya adalah sumber daya manusia oleh karena pentingnya peran manusia dalam kompetisi baik jangka pendek maupun jangka panjang dalam agenda bisnis, suatu organisasi harus memiliki nilai lebih dibandingkan dengan organisasi lainnya. Organisasi yang berhasil dalam mempengaruhi pasar jika dapat menarik perhatian atau kelebihan yang dimiliki dalam berbagai hal dibandingkan dengan organisasi lain.

Salah satu faktor yang sangat 
berpengaruh dalam sumber daya manusia adalah faktor kedisiplinan. Menurut Hasibuan(2013:23), kedisiplinan merupakan

fungsi manajemen sumber daya manusia (MSDM) yang terpenting dan kunci terwujudnya tujuan karena tanpa disiplin yang baik sulit terwujud tujuan yang maksimal.

PT.Multitran Cahaya Abadi adalah perusahaan yang bergerak dibidang jasa keuangan, berdasarkan observasi yang telah dilakukan oleh penulis, banyak Pegawai yang datang terlambat,banyak Pegawai yang tidak memakai seragam dan banyak Pegawai yang tidak sesuai dengan SOP. Menurut Greenberg (dalamSetiyana, V. Y. 2013:384) stress kerja adalah konstruk yang sangat sulit didefinisikan, stress dalam pekerjaan terjadi pada seseorang, dimana seseorang berlari dari masalah, sejak beberapa pekerja membawa tingkat pekerjaan pada kecenderungan stres, stress kerja sebagai kombinasi antara sumber-sumber stres pada pekerjaan, karakteristik individual, dan stresor di luar organisasi. Sedangkan menurut Hasibuan (2013:204) "stress kerja adalah suatu kondisi ketegangan yang mempengaruhi emosi, proses berpikir dan kondisi seseorang”. Dari dampak stress ini akan berakibat pada gangguan kesehatan sehingga berakibat terhadap kehadiran pegawai sehingga menurunnya disiplin kerja.Menurut Mangkunegara (2013),disiplin kerja diartikan sebagai pelaksanaan manajemen untuk memperteguh pedoman pedoman organisasi.Sedangkan menurut Hasibuan (2015), kedisiplinan adalah kunci keberhasilan suatu perusahaan dalam mencapai tujuan tujuannya.Untuk meningkatkan disiplin kerja terhadap karyawan ,perusahaan perlu menerapkan beberapa peraturan mengenai disiplin kerja yang harus ditaati,seperti memberikan sanksi hukuman bagi karyawan yang tidak mengikuti peraturan perusahaan. Beberapa aturan disiplin kerja guna membuat karyawan memiliki rasa tanggung jawab dalam bekerja, dan guna meningkatkan kinerja para karyawannya. Anwar Prabu Mangkunegara (2013:67) mengemukakan bahwa kinerja adalah hasil kerja secarakualitas dan kuantitas yang dicapai oleh seorang pegawai dalam melaksanakan tugasnya sesuai dengan tanggung jawab yang diberikan kepadanya. Sedangkan definisi kinerja karyawan menurut Kasmir (2016) "kinerja merupakan hasil kerja dan perilaku kerja seorang dalam suatu periode, biasanya 1 tahun".

Peneliti mengambil obyek penelitian pada PT. Cahaya Multitran Abadi Srengseng Jakarta Barat. PT. Cahaya Multitran Abadi Srengseng Jakarta Barat adalah perusahaan pengiriman barang dengan layanan service door to door keseluruh wilayah di Indonesia dan Internasional, melalui udara, darat dan laut. Dengan dukungan penuh jaringan agenagen di seluruh kota Indonesia, serta didukung juga oleh tenaga kerja Profesional, menjadi salah satu kekuatan dan andalan CMA dalam memberikan layanan pengiriman,paket maupun kargo secara aman dan tepat waktu. Dalam layanan pengiriman, paket maupun kargo pasti ada saja kendala 
yang dimiliki,maka penulis ingin mengulas factor penyebab terjadinya penambahan waktu kerja karyawan dalam pengiriman barang yang memungkinkan adanya factor stress kerja yang menjadi penyebabnya.

Penjelasan mengenai data absebsi di ketahui bahwa rata-rata tingkat keterlambatan karyawan PT Cahaya Multitran Abadi Srengseng Jakarta Barat sangat tinggi di setiap bulannya.Sehingga mencapai 218 kali. Keseluruhan total keterlambatan tersebut di peroleh dari jumlah karyawan yang terlambat di setiap harinya dan di jumlahkan pada setiap bulannya. Jumlah keterlambatan yang paling tinggi yaitu pada bulan November hingga mencapai sebanyak 25 kali.Kemudian tingkat mangkir karena alas an tertentu atau izin mencapai total 5 orang dan absen karena sakit sebanyak 7 orang. Dapat di lihat juga masih ada karyawan yang tidak masuk tanpa izin atau alfa pada bulan Februari sebanyak 6 kali.Hasil observasi yang penulis lakukan pada PT.Multitran Cahaya Abadi, bahwa disiplin yang diberikan oleh PT.Multitran Cahaya Abadi,

Kinerja mengacu pada prentasi kerja Pegawai diukur berdasarkan standar atau kriteria yang telah ditetapkan organisasi.Pengelolaan untuk mencapai kinerja Pegawai yang sangat tinggi terutama untuk meningkatkan kinerja organisasi secara keseluruhan. Menurut Marwansyah (2012:228), penilaian kinerja adalah sistem formal untuk memeriksa atau mengkaji dan mengevaluasi kinerja seseorang atau kelompok.Kinerja adalah pencapaian atau prestasi seseorang berkenaan dengan tugas tugas yang dibebankan kepadanya. Kinerja dapat pula dipandang sebagai perpaduan dari hasil kerja (apa yang dicapai sesorang) dan kompetensi (bagaimana sesorang mencapainya).

Kinerja Pegawai pada PT.Multitran Cahaya Abadimasih kurang maksimal dengan ditemukan banyaknya Pegawai yang tidak mengerti job desk, serta kurangnya pengawasan pada Pegawai dan Pegawai tidak tahu bagaimana menjalankan tugas-tugas secara benar, kurangnya keterampilan pengetahuan,atau kemampuan.Kinerja adalah proses menyeluruh untuk mengamati kinerja sesorang Pegawai dalam hubungannya dengan persyaratan jabatan selama jangka waktu tertentu (yakni, menjelaskan, menetapkan tujuan, memberikan bimbingan langsung tentang bagaimana melakukan pekerjaan, menyimpan dan mengakses informasi tentang kinerja) dan kemudian membuat penilaian tentang kinerja itu.

Hasil observasi yang penulis lakukan pada PT.Multitran Cahaya Abadi, bahwa kinerja yang diberikan oleh PT.Multitran Cahaya Abadi, hal ini dapat kita lihat pada tabel berikut ini:

Tabel 1.1

Penilaian kinerja Pegawai PT.Multitran Cahaya Abadi

\begin{tabular}{|c|c|c|}
\hline $\begin{array}{c}\text { Kriteria Penilain } \\
\text { Kinerja }\end{array}$ & $\begin{array}{c}\text { Bobot } \\
(\%)\end{array}$ & $\begin{array}{c}\text { Pencapaian } \\
(\%)\end{array}$ \\
\hline Tujuan & 35 & 25 \\
\hline Kompetensi & 20 & 20 \\
\hline
\end{tabular}




\begin{tabular}{|c|c|c|}
\hline Alat dan Sarana & 20 & 15 \\
\hline Motif & 15 & 10 \\
\hline Peluang & 10 & 10 \\
\hline Total & $100 \%$ & $80 \%$ \\
\hline
\end{tabular}

Sumber: PT.Multitran Cahaya

\section{Abadi}

Mengingat pentingnya masalah tersebut maka penulis melakukan penelitian ini agar dapat memberikan manfaat bagi organisasi dalam memberikan motivasi kepada Pegawai sehingga tujuan organisasi dapat tercapai.Berdasarkan uraian latar belakang tersebut di atas, maka di ajukan penelitian dengan judul "Pengaruh Sters Kerja Disiplin Terhadap Kinerja Pegawai Pada PT.Multitran Cahaya Abadi, Srengseng Jakarta Barat”.

\section{METODE PENELITIAN}

Metode penelitian yang digunakan adalah metode kuantitatif. Menurut Sugiyono (2016), "Metode kuantitatif dapat diartikan sebagai metode penelitian yang berlandaskan pada filsafat positivisme, digunakan untuk meneliti pada populasi atau sample tertentu, pengumpulan data menggunakan instrumen penelitian, analisis data bersifat kuantitatif/statistik, dengan tujuan untuk menguji hipotesis yang telah ditetapkan”.

Desain penelitian merupakan bagian dari perencanaan penelitian yang menunjukan penelitian untuk melihat apakah penelitian yang direncanakan telah memiliki validitas internal dan validitas eksternal yang komprehensif. Berdasakan rumusan dan tujuan sebelumnya, metode penelitian yang digunakan penulis adalah metode deskriptif, yaitu yang mengungkapkan gambaran masalah yang terjadi pada saat penelitian ini berlangsung.

Yang dimaksud "Teknik sampling adalah merupakan teknik pengambilan sample, untuk menentukan sampel yang akan digunakan dalam penelitian" Sugiyono (2016), dalam penelitian ini penulis menggunakan metode simpel random sampling, dimana semua data yang di dapat dijadikan sampel.

\section{HASIL DAN PEMBAHASAN}

\section{A. Analisis Kualitas Data}

Berdasarkan hasil penyebaran kuisioner terhadap 50 responden yang merupakan karyawan PT Cahaya Multitran Abadi Srengseng Jakarta Barat Alam Sutera maka dapat diketahui gambaran tentang frekuensi jenis kelamin dan usia responden:

1. Deskripsi Berdasarkan Jenis Kelamin Berdasarkan data penelitian yang diperoleh dari penyebaran kuisioner maka diperoleh data tentang jenis kelamin responden yang bekerja di PT Cahaya Multitran Abadi Srengseng Jakarta Barat Dari tabel tersebut bahwa terlihat mayoritas pekerja di PT Cahaya Multitran Abadi Srengseng Jakarta Barat adalah laki-laki diman diperoleh $54 \%$ 
karena memang hampir semua barang yang dijual oleh PT Cahaya Multitran Abadi Srengseng Jakarta Barat adalah barangbarang berat, kemudian disusul oleh perempuan yaitu $46 \%$.

2. Deskripsi Berdasarkan Pendidikan bahwa mayoritas pekerja adalah berpendidikan SMK dimana diperoleh sebanyk 36\% kemudian disusul oleh berpendidikan S1 yaitu $34 \%$.

\section{Metode Penilaian atau Deskriptif Variabel Penelitian}

Berdasarkan kuisioner yang di sebarkan kepada responden, maka dapat diketahui pernyataan responden mengenai tanggapan responden atas motivsi dan displin terhadap kinerja karyawan kerja dimana setiap jawaban di nilai dengan skala Likert yaitu setiap pernyataan mengandung lima alternatif jawaban yaiitu: $P=$ Rentang

\section{Banyak KeS}

Jadi panjang kelas interval sebagai berikut: P mayoritas pekerja di PT Cahaya Multitran Abadi Srengseng Jakarta Barat adalah berusia $27-31$ th sebanyak $36 \%$ hal ini dikarenakan usia tersebut adalah masa produktif manusia bekerja.

Dengan demikian kategori skala dapat ditentukan sebagai berikut :

1,00-1,79 : Sangat

Tidak Baik 1,80-2,59:

Kurang Baik
2,60 - 3,39: Cukup Baik

3,40 - 4,19: Baik

4,20 - 5,00: Sangat Baik

Berdasarkan abel 4.4 maka terlihat nilai ratarata yaitu 40,04 berada di range $(3,40-4,19$ : Baik) dimana tanggap responden terhadap variabel stress kerja $\left(x_{1}\right)$ miliki range baik, dimana stress kerja yang diberikan oleh pimpinan terhadap karyawan sudah baik terlebih dilihat dari skor tertinggi 4,28 yaitu pada indi kator "Aktualisasi" dimana Atasan memberikan penilaian atau kritik langsung kepada karyawan sehingga dapat lebih meningkatkan lagi kerja karyawan. Disamping itu pihak perusahaan harus lebih meningkatkan stress kerja pada indikator "Pengahargaa" dimana merupakan skor terendah yaitu 3,10 pada pernyataan Karyawan yang berprestasi akan di berikan penghargaan oleh perusahaan. Dimana karyawan yang berprestasi tidak semua nya diberikan penghargaan oleh PTCahaya Multitran Abadi Srengseng Jakarta Barat ,maka dari itu PT Cahaya Multitran Abadi Srengseng Jakarta Barat harus leih memperhatikan karyawannya Berdasarkan abel 4.5 maka terlihat nilai ratarata yaitu 41,64 berada di range $(4,20-5,00$ : Sangat Baik) dimana tanggap responden terhadap variabel disiplin $\left(x_{2}\right)$ meiliki range baik, dimana disiplin yang ada sudah baik terlebih dilihat dari skor tertinggi 4,24 yaitu pada indi kator "Ketegasan" dimana Pimpinan yang bijaksana dan tegas sangat berpengaruh terhada tingkat kedisiplinan sehingga pemimpin di PT Cahaya Multitran 
Abadi Srengseng Jakarta Barat sudah bertindak tegas kepada karyawan yang tidak Disiplin terhadap peraturan yang ada pada PT Cahaya Multitran Abadi Srengseng Jakarta Barat . Disamping itu pihak perusahaan harus lebih meningkatkan kedisiplinan pada indikator "Balasa Jasa" dimana merupakan skor terendah yaitu 4,06 sehingga Imbalan yang di berikan perusahaan harus sesuai dengan beban kerja yang di berikan karyawan. Karena masih ada karyawan yang lembur dan tidak mendapatkan imbalan yang sesuai dengan jam kerja nya. Maka dari itu PT Cahaya Multitran Abadi Srengseng Jakarta Barat harus lebih memperhatikan nasib karyawanya. Berdasarkan abel 4.6 maka terlihat nilai rata- rata yaitu 39,84 berada di range $(3,40-4,19$ : Baik) dimana tanggap responden terhadap variabel kinerja karyawan (y) meiliki range baik, dimana disiplin yang ada sudah baik terlebih dilihat dari skor tertinggi 4,00 yaitu pada indi kator "Meningkatkan Hasil yang dicapai" dimana Karyawan berusaha untuk meningkatkan hasil yang di capai dalam setiap pekerjaan yang dilakukan. Disamping itu pihak perusahaan harus lebih meningkatkan produktiiftas pada indikator "Pengembangan Diri" dimana merupakan skor terendah yaitu 3,96 dimana karyawan yang bekerja harus melakukan Pengembangan diri mutlak di lakukan oleh karyawan untuk menjadi lebih baik maka dari itu PT Cahaya Multitran Abadi Srengseng Jakarta Barat dapat memberikan fasilitas kepada karyawannya demi meningkatkan kinerja karyawan kerja karyawanya.
Tabel 1.1 Hasil Output SPSS 23 Uji

\begin{tabular}{|c|c|c|c|c|c|c|}
\hline \multirow[b]{2}{*}{ Model } & & \multicolumn{2}{|c|}{ Unstandardized Coefficients } & \multirow{2}{*}{$\frac{\begin{array}{c}\text { Standardized } \\
\text { Coefficients }\end{array}}{\text { Beta }}$} & \multicolumn{2}{|c|}{ Collinearity Staijsics } \\
\hline & & \multirow{2}{*}{$\begin{array}{l}\text { B } \\
18.565\end{array}$} & \multirow{2}{*}{$\begin{array}{l}\text { Std. Error } \\
7.194\end{array}$} & & \multirow[t]{2}{*}{ Tolerance } & \multirow[t]{2}{*}{ VF } \\
\hline 1 & (Constant) & & & & & \\
\hline & Molvasi & .101 & .237 & .076 & .537 & 1.862 \\
\hline & Disiplin & .414 & .196 & 378 & .537 & 1.862 \\
\hline
\end{tabular}

Sumber: Data Primer, 2018

(1) Stress kerja (X1) memiliki nilai

Tolerance Value : 0,537>0,01 atau

VIF $: 1,862<10.00$.

(2) Disiplin (X2) memiliki nilai Tolerance Value : 0,537>0,01 atau VIF : 1,862 < 10.00

Sehingga dapat disimpulkan dalam penelitian ini bebas dari adanya multikolinearitas dan semua variabel bebas yang dipakai dalam penelitian ini lolos gelaja multikolinearitas.

\section{Uji Heteroskedastisitas}

Uji Heteroskedastisitas bertujuan menguji apakah dalam regresi terjadi ketidaksamaan variance dari residual suatu pengamatan ke pengamatan yang lain. Heteroskedastisitas menunjukkan penyebaran variabel bebas. Penyebaran yang acak menunjukkan model regresi yang baik. Dengan kata lain tidak terjadi heteroskedastisitas. Untuk menguji heteroskedastisitas dapat dilakukan dengan mengamati grafik scatterplot dengan pola titik-titik yang menyebar di atas dan di bawah sumbu Y. Berikut hasil pengolahan menggunakan program SPSS 23:ini.

\section{B. Analisis Regresi Linear Berganda}

Berdasarkan analisis dengan program SPSS 23 for Windows diperoleh hasil regresi 
berganda

Konstanta sebesar 18,565 menyatakan bahwa tanpa ada variabel stress kerja $\left(x_{1}\right)$ dan disiplin ( $x_{2}$ maka kinerja karyawan (y) tetap terbentuk sebesar 18,565 atau jika niali stress kerja $\left(x_{1}\right)$ dan disiplin $\left(x_{2}\right)$ nilainya $=0$ maka kinerja karyawan tetap memiliki nilai $=18,565$. Yang artinya karyawan akan tetap bekerja seuai target demi tercapai nya kinerja karyawan kerja yang masksimal meski tidak ada faktor stress kerja $\left(x_{1}\right)$ dan disiplin $\left(x_{2}\right)$ karena pada dasarnya bekerja dengan baik merupakan tanggung jawabn dari setiap karyawan.

1. Variabel stress kerja $\left(x_{l}\right)$ berpengaruh positif terhadap kinerja karyawan (y) dengan nilai koefisien sebesar 0,101 . Artinya jika variabel stress kerja $\left(x_{1}\right)$ meningkat satu-satuan dengan asumsi bahwa variabel disiplin $\left(x_{2}\right)$ tetap, maka kinerja karyawan (y) akan meningkat sebesar 0,101 .

2. Variabel disiplin $\left(x_{2}\right)$ berpengaruh positif terhadap kinerja karyawan (y) dengan nilai koefisien sebesar 0,414. Artinya jika variabel disiplin $\left(x_{2}\right)$ meningkat satu-satuan dengan asumsi bahwa variabel stress kerja $\left(x_{1}\right)$, tetap, maka kinerja karyawan akan meningkat sebesar 0,414 .

\section{Pengujian Hipotesis}

Analisis data untuk pengujian hipotesis ini dalam penelitian ini menggunakan regresi linier ganda dengan variabel bebas stress kerja $\left(x_{1}\right)$, disiplin $\left(x_{2}\right)$, serta kinerja karyawan kerja karyawan sebagai variabel terikat. Dalam analisis ini diuji secara parsial dan simultan

\section{Uji Parsial (Uji t)}

Uji $t$ dilakukan untuk mengetahui pengaruh masing-masing atau secara parsial variabel indenpenden $\mathrm{x}_{1}$ (stress kerja ) dan $\mathrm{x}_{2}$ (disiplin) terhadap variabel dependen kinerja karyawan (y). Dan menentukan variabel manakah yang paling domonan mempengaruhi kinerja karyawan , sehingga dapat ditunjukan pada tabel berikut ini:

Pengaruh dari masing-masing variabel $\mathrm{x}_{1}$ (stress kerja) dan $\mathrm{x}_{2}$ (disiplin) terhadap kinerja karyawan (y) dapat dilihari dari arah tanda dan tingkat signifikansi (probablitas) dimana semua variabel mempunyai arah yang positif dan berpengaruh signifikan karena nlai signifkansi $<0,05$. atau pada $t$ tabel dengan nilai signifkasi 0,05 maka diperoleh $\mathrm{t}$ tabel 1,985 atau $=\operatorname{TINV}(0,05 ; 47)$ : maka 2,012

a. Pengaruh Stress kerja $\left(x_{1}\right)$ terhadap kinerja karyawan

Hasil uji parsial (uji t) antara stress kerja terhadap kinerja karyawan menunjukan nilai $\mathrm{t}$ hitung $>\mathrm{t}$ tabel $(2,427>2,012)$ dan sig < 0,05 $(0,012$ $<0,05)$ sehingga Ho di tolak dan Ha diterima yaitu " terdapat pengaruh variabel stress kerja terhadap kinerja karyawan kerja karyawan.

b. Pengaruh Disiplin $\left(x_{2}\right)$ terhadap kinerja karyawan

Hasil uji parsial (uji t) antara disiplin 
terhadap kinerja karyawan menunjukan nilai $\mathrm{t}$ hitung $>\mathrm{t}$ tabel $(2,111>2,012)$ dan sig $<0,05(0,040<$ 0,05) sehingga $\mathrm{Ha}$ di terima dan $\mathrm{Ho}$ ditolak yaitu terdapat pengaruh variabel disiplin kerja terhadap kinerja karyawan kerja karyawan.

\section{Uji Simultan (Uji F)}

Uji statistik F pada dasarnya menunjukan apakah semua variabel independen yang dimasukan dalam model mempunyai pengaruh secara bersmaa-sama terhadap variabel dependenya. Hasil perhitungan Uji F dapat dilihat pada tabel: Untuk menguji pengaruh $\mathrm{x}_{1}$ (stress kerja) dan $\mathrm{x}_{2}$ (disiplin) terhadap kinerja karyawan (y) dapat digunakan uji statistik F (uji F), dengan menggunakan taraf signifikansi $5 \%(0,05)$ dan drajat kebebasan dengan rumus $\mathrm{dk}=\mathrm{n}-\mathrm{k}-1$, dimana $n$ adalah nilai jumlah mahasiswa dan $k$ adalah jumlah variabel yang diteliti, dengan dasar pengambilan keputusannya adalah dengan menggunakan angka probabilitas signifikasi, yaitu:

a. Apabila probabilitas signifikansi > 0,05 dan $\mathrm{F}$ hitung $<\mathrm{F}_{\text {tabel }}$ maka $\mathrm{H}_{03}$ diterima dan $\mathrm{H}_{\mathrm{a} 3}$ ditolak

b. Apabila probabilitas signifikansi < 0,05 dan $\mathrm{F}$ hitung $>\mathrm{F}_{\text {tabel }}$ maka $\mathrm{H}_{\mathrm{o3}}$ ditolak dan $\mathrm{H}_{\mathrm{a} 3}$ diterima

$\mathrm{F}_{\text {hitung }}$ dan $\mathrm{F}_{\text {tabel }}$

F hitung adalah 5,457 (lihat pada

tabel anova)

F tabel dapat dicari pada tabel statistik pada signifikansi 0,05 :

Ho $3: \beta_{1}=\beta_{2}=\beta_{3}=0$ : Diduga tidak terdapat pengaruh variabel stress kerja $\left(\mathrm{X}_{1}\right)$ dan disiplin kerja $\left(\mathrm{X}_{2}\right)$ terhadap kinerja karyawan karyawan (Y).

Ha $: \beta_{1 \neq} \beta_{2} \neq \beta_{3} \neq 0$ : Diduga terdapat pengaruh variabel stress kerja $\left(\mathrm{X}_{1}\right)$ dan disiplin kerja $\left(\mathrm{X}_{2}\right)$ terhadap kinerja karyawan karyawan (Y).

Berdasarkan tabel 4.15 hasil uji Anova dapat diperoelh nilai $F_{\text {hitung }}>$ $\mathrm{f}_{\text {tabel }}$ yaitu 5,457 > 3,195 dan nilai sig $<0,05$ atau $0,007<0,005$ maka $\mathrm{H}_{03}$ ditolak dan $\mathrm{H}_{\mathrm{a} 3}$ diterima yaitu terdapat terdapat pengaruh variabel stress kerja $\left(X_{1}\right)$ dan $\operatorname{disiplin}\left(X_{2}\right)$ terhadap kinerja karyawan (Y) secara bersama-sama..

\section{PEMBAHASAN}

\section{Variabel Stres kerja}

a. Tanggap responden terhadap variabel stress kerja $\left(x_{l}\right)$ miliki range baik,

Berdasarkan terlihat nilai rata-rata yaitu 40,04 berada di range $(3,40-4,19$ : Baik ) dimana stress kerja yang diberikan oleh pimpinan terhadap karyawan sudah baik terlebih dilihat dari skor tertinggi 4,28 yaitu pada indikator "Aktualisasi" dimana Atasan memberikan penilaian atau kritik langsung kepada karyawan 
sehingga dapat lebih meningkatkan lagi kerja karyawan. Dimana merupakan skor terendah yaitu 3,10 pada pernyataan Karyawan yang berprestasi akan di berikan penghargaan oleh perusahaan. Dimana karyawan yang berprestasi tidak semua nya diberikan penghargaan oleh PT Cahaya Multitran Abadi Srengseng Jakarta Barat , maka dari itu PT Cahaya Multitran Abadi Srengseng Jakarta Barat harus leih memperhatikan karyawannya.

b. Berdarkan hasil uji validitas maka item kuisioner no $1 \mathrm{r}$ hitung $(0,508)>$ $r$ tabel $(0,279)$

c. Berdarkan hasil uji reliabitas maka item kuisioner $\mathrm{r}$ ca $(0,528)>\mathrm{r}$ tabel $(0,279)$

d. Hasil uji parsial (uji t) antara stress kerja terhadap kinerja karyawan menunjukan nilai $\mathrm{t}$ hitung $>\mathrm{t}$ tabel $(2,427>2,012)$ dan $\mathrm{sig}<0,05(0,012$ $<0,05)$ sehingga Ho di tolak dan Ha diterima yaitu " terdapat pengaruh variabel stress kerja terhadap kinerja karyawan kerja karyawan. Hasil ini sejalan dengan penelitian dari Riduan (2008), Marsono (2013), Elpis (2013) dan Nur (2014).

\section{Variabel Disiplin}

a. Tanggap responden terhadap variabel disiplin $\left(x_{2}\right)$ meiliki range baik, terlihat nilai rata-rata yaitu 41,64 berada di range $(4,20 \quad 5,00$ Sangat Baik) dimana disiplin yang ada sudah baik terlebih dilihat dari skor tertinggi 4,24 yaitu pada indi kator "Ketegasan" dimana Pimpinan yang bijaksana dan tegas sangat berpengaruh terhadap tingkat kedisiplinan sehingga pemimpin di PT Cahaya Multitran Abadi Srengseng Jakarta Barat sudah bertindak tegas kepada karyawan yang tidak Disiplin terhadap peraturan yang ada pada PT Cahaya Multitran Abadi Srengseng Jakarta Barat . Namun disamping itu pihak perusahaan harus lebih meningkatkan kedisiplinan pada indikator "Balasa Jasa" dimana merupakan skor terendah yaitu 4,06 sehingga Imbalan yang di berikan perusahaan harus sesuai dengan beban kerja yang di berikan karyawan. Karena masih ada karyawan yang lembur dan tidak mendapatkan imbalan yang sesuai dengan jam kerja nya. Maka dari itu PT Cahaya Multitran Abadi Srengseng Jakarta Barat harus lebih memperhatikan nasib karyawanya

b. Berdarkan hasil uji validitas maka item kuisioner no $1 \mathrm{r}$ hitung $(0,596)>$ $r$ tabel $(0,279)$

c. Berdarkan hasil uji reliabitas maka item kuisioner $r$ ca $(0,774)>r$ tabel $(0,279)$

d. Hasil uji parsial (uji t) antara disiplin terhadap kinerja karyawan menunjukan nilai $\mathrm{t}$ hitung $>\mathrm{t}$ tabel $(2,111>2,012)$ dan sig < $0,05(0,040$ $<0,05$ ) sehingga Ha di terima dan Ho 
ditolak yaitu terdapat pengaruh variabel disiplin kerja terhadap kinerja karyawan. Hasil penelitina ini sesuai dengan penelitian dari Marsono (2013), Elpis (2013), Try (2013) dan Nur (2014)

\section{Variabel Kinerja karyawan}

a. Tanggap responden terhadap variabel kinerja karyawan meliki range baik,maka terlihat nilai ratarata yaitu 39,84 berada di range (3,40 - 4,19: Baik) dimana dimana disiplin yang ada sudah baik terlebih dilihat dari skor tertinggi 4,00 yaitu pada indi kator "Meningkatkan Hasil yang dicapai" dimana Karyawan berusaha untuk meningkatkan hasil yang di capai dalam setiap pekerjaan yang dilakukan, namun disamping itu pihak perusahaan harus lebih meningkatkan produktiiftas pada indikator "Pengembangan Diri" dimana merupakan skor terendah yaitu 3,96 dimana karyawan yang bekerja harus melakukan Pengembangan diri mutlak di lakukan oleh karyawan untuk menjadi lebih baik maka dari itu PT Cahaya Multitran Abadi Srengseng Jakarta Barat dapat memberikan fasilitas kepada karyawannya demi meningkatkan kinerja karyawan kerja karyawanya. b. Berdarkan hasil uji validitas maka item kuisioner no $1 \mathrm{r}$ hitung $(0,590)$ $>\mathrm{r}$ tabel $(0,279)$

c. Berdarkan hasil uji reliabitas maka item kuisioner $r$ ca $(0,825)>r$ tabel $(0,279)$

d. Berdasarkan hasil uji Anova dapat diperoelh nilai $\mathrm{F}_{\text {hitung }}>\mathrm{f}$ tabel yaitu $5,457>3,195$ dan nilai sig $<0,05$ atau $0,007<0,005$ maka $\mathrm{H}_{03}$ ditolak dan $\mathrm{H}_{\mathrm{a} 3}$ diterima yaitu terdapat terdapat pengaruh variabel stress kerja $\left(X_{1}\right)$ dan $\operatorname{disiplin}\left(X_{2}\right)$ terhadap kinerja karyawan (Y) secara bersama- sama. Hal ini sejalan dengan penelitian Nur (2014), Elpis (2013), Riduan (2008)

\section{SIMPULAN}

Berdasarkan hasil penelitian menunjukkan bahwa, Terdapat pengaruh stress kerja terhadap kinerja karyawan kerja karyawan PT Cahaya Multitran Abadi Srengseng Jakarta Barat ialah sebesar 2,427 hal ini dilihat dari hasil uji hipotesis, sehingga terdapat pengaruh stress kerja terhadap kinerja karyawan kerja karyawan PT Cahaya Multitran Abadi Srengseng Jakarta Barat .Unutuk mengetahui seberapa besar pengaruh disiplin terhadap kinerja karyawan kerja karyawan PT Cahaya Multitran Abadi Srengseng Jakarta Barat . Sesuai dengan rumusan masalah maka besar nya pengaruh disiplin terhadap kinerja 
karyawan kerja karyawan PT Cahaya Multitran Abadi Srengseng Jakarta Barat ialah sebesar 2,111 hal ini dilihat dari hasil uji hipotesis, sehingga terdapat pengaruh disiplin terhadap kinerja karyawan kerja karyawan PT Cahaya Multitran Abadi Srengseng Jakarta Barat .Unutuk mengetahui seberapa besar pengaruh stress kerja dan disiplin terhadap kinerja karyawan kerja karyawan PT Cahaya Multitran Abadi Srengseng Jakarta Barat . Sesuai dengan rumusan masalah maka besar nya pengaruh stress kerja dan disiplin terhadap kinerja karyawan kerja karyawan PT Cahaya Multitran Abadi Srengseng Jakarta Barat adalah 5,457 hal ini dilihat dari hasil uji anova atau keseluruhan sehingga terdapat pengaruh stress kerja dan disiplin terhadap kinerja karyawan kerja karyawan PT Cahaya Multitran Abadi Srengseng Jakarta Barat

\section{DAFTAR PUSTAKA}

Ardana. 2012. Manajemen Sumber Daya Manusia. Yogyakarta : Graha Ilmu

Arikunto, Suharsimi. 2014. Prosedur Penelitian Suatu Pendekatan Praktik. Jakarta: Rineka Cipta

Bangun, Wilson. 2012. Manajemen Sumber Daya Manusia. Semarang : PT. Rineka Cipta

Ghozali. 2014. Aplikasi Analisis Multivariate Dengan Program SPSS. Semarang, Badan Penerbit

\section{Undip}

Hasan, Iqbal. 2014. Analisis Data Dengan Statistik. Jakarta : Bumi Aksara

Krisnaldy, K., Pasaribu, V. L. D., \& Senen, S. (2019). Pengaruh Budaya Organisasi, Lingkungan Kerja Dan Iklim Organisasi Terhadap Motivasi Pegawai Serta Dampaknya Terhadap Kepuasan Kerja. Jurnal Semarak, 2(2), 164-183.

Krisnaldy, K., Pasaribu, V. L. D., \& Batubara, A.

S. (2020). Analisis Pengaruh Kedisiplinan Terhadap Performa Pegawai Kelurahan Rempoa, Kota Tangerang Selatan. Jurnal Mandiri: Ilmu Pengetahuan, Seni, Dan Teknologi, 4(2), 131-138.

Pasaribu, V. L. D., Krisnaldy, K., \& Warasto, H. N. (2020). Pengaruh Gaya Kepemimpinan, Disiplin Kerja Dan Kompensasi Terhadap Kinerja Pegawai (Studi kasus kelurahan Pisangan Ciputat). Jurnal Disrupsi Bisnis: Jurnal Ilmiah Prodi Manajemen, Fakultas Ekonomi, Universitas Pamulang, $3(1)$.

Pratama, A. (2020). Pengaruh Kompensasi Dan Disiplin Kerja Terhadap Kinerja Karyawan Pada PT Pos Indonesia DC Ciputat. Jurnal Disrupsi Bisnis: Jurnal Ilmiah Prodi Manajemen, Fakultas Ekonomi, Universitas Pamulang, 3(2), 12-24.

Rivai, Veithzal. 2011. Manajemen Sumber Daya Manusia Untuk Perusahaan. Jakarta, Raja Grafindo Persada

Robins, Stephen P. 2011. Organizational Behavior, Edisi Keduabelas, Pretince Hall

Sugiarti, E. (2018). Pengaruh Kedisiplinan terhadap Kinerja Pegawai pada Badan Meteorologi Klimatologi dan 
Geofisika Wilayah II Ciputat. KREATIF: Jurnal Ilmiah Prodi Manajemen Universitas Pamulang, 6(3), 49-58.

Sujarweni. 2014. Metode Penelitian Lengkap, Praktis, dan Mudah Dipahami. Yogyakarta: Pustaka Baru Press

Suryani, N. L. (2020). Pengaruh Pengembangan Karir Dan Disiplin Terhadap Kepuasan Kerja Karyawan Pada PT. Qeon Interactive-Jakarta Pusat. JENIUS (Jurnal Ilmiah Manajemen Sumber Daya Manusia), 3(2), 208-220.

Sutrisno, Edy. 2011. Manajemen Sumber Daya manusia. Jakarta : Kencana

Yusup, Pawit M. 2012. Pengantar Sistem Informasi, Edisi Pertama, Yogyakarta : Graha Ilmu 